\title{
New challenges in soil management
}

\author{
MÁRTA BIRKÁS \\ Szent István University, Faculty of Agricultural and Environmental Sciences, \\ Gödöllő, Hungary \\ birkas.marta@mkk.szie.hu
}

\begin{abstract}
Summary
Soil management represents two important tasks that are harmonization of the soil protection with demands of the crop to be grown on the given land under prevailing farming condition. Further goals are to preserve and/or develop the soil physical, biological and chemical condition and to avoid the unfavourable changes of the soil biological activity and the soil structure.

Classical authors emphasised the importance of creating proper seedbed for plants. In the physical approach, tillage was believed to play an important role in controlling soil processes. Consequently, the period of several centuries dominated by this approach is referred to as the era of crop-oriented tillage (Birkás et al., 2017). The overestimation of the importance of crop requirements resulted in damaging the soils, which inevitably led to turn to the soil-focused tillage. Since the first years of climate change, as the new trends have raised concern, tillage must be turned into a climate-focused effort with the aim of reducing climate-induced stresses through improving soil quality.

The development of soil management has always been determined by the economical background. At the same time, deteriorating site conditions have contributed to the conception of new tillage trends by forcing producers to find new solutions (e.g. dry farming theory in the past or adaptable tillage theory nowadays). Gyobrffy (2009) recited the most important keywords were listed in 2001 and that seemed to be important in the future of crop production. These keywords (endeavours) were as follows:

- Biofarming, organic farming, alternative farming, biodynamic farming, low input sustainable agriculture;

- Mid-tech farming, sustainable agriculture, soil conservation farming, no till farming, environmentally sound, environmentally friendly, diversity farming;

- Crop production system, integrated pest management, integrated farming, high-tech farming;

- Site specific production, site-specific technology, spatial variable technology, satellite farming;

- Precision farming.

Győrffy's prognosis proved to be realistic and the efforts mentioned above have mostly been implemented. New challenges have also appeared in soil management in relation to the last decades. The most important endeavours for the future are:

1) Preserving climate-induced stresses endangering soils.

2) Turn to use climate mitigation soil tillage and crop production systems.
\end{abstract}


3) Applying soil management methods are adaptable to the different soil moisture content (over dried or wet may be quite common).

4) Use effectual water conservation tillage.

5) Use soil condition specific tillage depth and method.

6) Adapting the water and soil conservation methods in irrigation.

7) Preserving and improving soil organic matter content by tillage and crop production systems.

8) Considering that stubble residues are matter for soil protection, humus source and earthworm' feed.

9) Site-specific adoption of green manure and cover crops.

10) Applying site-adopted (precision) fertilization and crop protection. Considering the development in agriculture, new endeavours will occur before long.

Keywords: soil-oriented tillage, climate

\section{References}

Birkás, M.-Dekemati, I.-Kende, Z.-Pósa, B. (2017): Review of soil tillage history and new challenges in Hungary. Hungarian Geographical Bulletin. 66. 1: 55-64.

Győrffy B. (2001): Javaslat a precíziós agrárgazdaság kutatási programjának indítására. MTA Agrártudományok Osztályának 2000. évi Tájékoztatója. Budapest. 17-22.

Győrffy B. (2009): A biogazdálkodástól a precíziós mezőgazdaságig. Acta Agr. Debreceniensis. 2. 9: 81-86. (utánközlés) 